\title{
Zu Quellennachweisen und Transkription
}

Quellenangaben stehen, soweit möglich, in Kurzform direkt im Text. Genannt werden der Name des Autors und die Seitenangabe; mehrere Werke des gleichen Autors werden durch zusätzliche Angabe der Jahreszahl unterschieden. Die Schriften Ğãbirīs und einige Nachschlagewerke werden nach den im Literaturverzeichnis angegebenen Siglen zitiert. In den Fußnoten in ganzer Länge angegebene Literatur erscheint nicht in der Literaturliste.

Die Transkription richtet sich nach der von der Deutschen Morgenländischen Gesellschaft empfohlenen Systematik. Die Transkription in Zitaten wurde angeglichen. Im Deutschen geläufige Namen und Begriffe sind nicht transkribiert: Es steht also "Koran" anstelle von "Qur'ān". Das gilt nicht bei der Wiedergabe von arabischen Sätzen in Umschrift. Bei Koranzitaten übernehme ich die Übersetzung von Rudi Paret. 
